\title{
THE TRADITION OF THE ATHENIAN DEMOCRACY
}

$$
\text { A.D. } 1750-1990
$$

\author{
By MOGENS HERMAN HANSEN
}

By 1994 no less than 2,500 years will have passed since Kleisthenes (in 507 B.C. $)^{1}$ introduced democracy to Athens, and the anniversary will undoubtedly be celebrated by all nations that call themselves democracies, i.e., practically everywhere in the western world. But during the celebrations sceptics will probably ask at least two fundamental questions: first, how much do Athenian demokratia and modern democracy have in common and second, to what extent were modern democratic ideas and institutions shaped by looking back upon the ancient model? Was Athens the school not only of Hellas - as Perikles claimed in his funeral speach ${ }^{2}$ - but also of the political system and ideology that are universally accepted in the western world of today? Or, alternatively, is the Athenian example just one small piece in the great jigsaw puzzle that constitutes modern democracy and even a fairly unimportant piece, one of those elusive pieces that has nothing but sky or water on it and, accordingly, is almost impossible to place correctly?

I will answer the first question fairly briefly by comparing a standard definition of contemporary democracy with an ancient description of Athenian demokratia. In the 15th edition of the Encyclopaedia Britannica the opening of the entry democracy runs as follows: ${ }^{3}$

Democracy is a form of government based upon self-rule of the people and in modern times upon freely elected representative institutions and an executive responsible to the people, and a way of life based upon the fundamental assumption of the equality of all individuals and of their equal right to life, liberty (including the liberty of thought and expression) and the pursuit of happiness.

In Perikles' funeral oration Thucydides offers the following well known description of Athenian demokratia: ${ }^{4}$

[Our constitution] has the name democracy (demokratia) because government is in the hands not of the few but of the majority. ${ }^{5}$ In private disputes all are equal before the law (pasi to ison); and when it comes to esteem in public affairs, a man is preferred according to his own reputation for something, not, as a whole, just turn and turn about, ${ }^{6}$ but for excellence, and even in poverty no man is debarred by obscurity of reputation so long as he has it 
in him to do some good service to the state. Freedom (eleutheros) is a feature of our public life; and as for suspicion of one another in our daily private pursuits, we do not frown on our neighbour if he behaves to please himself or set our faces in those expressions of disapproval that are so disagreeable, however harmless.

These two passages illustrate - in my opinion - a striking similarity between ancient Athenian demokratia and modern liberal democracy: just like demokratia democracy is both a political system and a political ideology; as a political system it is rule by the people (though through representatives and no longer direct rule by the citizens in assembly); as a political ideology it is inextricably bound up with liberty and equality; and it presupposes an essential distinction between a public sphere and a private sphere.

For a detailed comparison of demokratia and democracy I refer to my account Was Athens a Democracy?, ${ }^{7}$ and will here address the second of the questions I stated above: why this striking similarity between contemporary liberal democracy and ancient Athenian demokratia? The explanation preferred by some classicists, and sometimes advocated by political scientists and philosophers as well, is that the modern democratic ideals were inspired and shaped by a strong classical tradition, and that modern democracy would not have taken the form it has today if it had not been for the classical tradition in general and the tradition of the Athenian democratic ideals in particular. Furthermore, it is believed that this classical tradition had its strongest impact on political thought during the Enlightenment in the second half of the 18th century. Accordingly, students of the classical origins of modern democracy tend to focus on the American and French revolutions as the two principal events through which ancient demokratia left its mark on modern democracy. ${ }^{8}$ I will refer to the contemporary political philosopher Hanna Arendt as an exponent of this view. In her book On Revolution she analyses the intellectual background of the American and French revolutions and writes that 'without the classical example ... none of the men of the revolution on either side of the Atlantic would have possessed the courage for what then turned out to be unprecedented action'. 'The classical example' is a sweeping expression; it covers all aspects of the Greek and Roman world. To what extent was the tradition of Athenian democracy an important element in the classical tradition that - allegedly - inspired the revolutionaries on either side of the Atlantic and paved the way for modern democracy? 


\section{Greek Democracy versus Athenian Democracy}

In any discussion of the impact of ancient democracy on modern political thought an important - but often disregarded - distinction is between the tradition of Greek democracy in general and the tradition of Athenian democracy in particular. In political philosophy from c. 1200 to $c .1800$ references to ancient democracy are almost always derived from the descriptions of democracy found in Aristotle's Politics, in Plato's dialogues (especially the Statesman and the Republic Books 8-9), and in Polybios Book 6.

In these works Plato, Aristotle, and Polybios discuss democracy in general and there are very few references to Athenian democracy. Admittedly, Athens, and especially 5th-century Athens, had been the model of many democracies all over classical Greece, ${ }^{10}$ but Athens was an oversized polis with many political institutions not found in other Greek cities; ${ }^{11}$ and we must not forget that, in the age of Plato and Aristotle, democracy was the most common form of constitution probably to be found in one form or another in hundreds of the Greek city states. ${ }^{12}$ Moreover, Plato and Aristotle are rightly praised for their faculty of generalization. Plato refers explicitly to Athenian democracy in his early dialogues, for example in the Gorgias,$^{13}$ and has many more implicit discussions of Athenian institutions in the Laws, ${ }^{14}$ but the discussions of democracy found in the Republic and in the Statesman have hardly any mention of Athens, apart from a concealed reference to the trial of Socrates.$^{15}$ Next, of about 300 historical examples adduced by Aristotle in the Politics no more than thirty concern Athens, and a third of those are to the tyranny of the Peisistratids in the 6th century or to the oligarchic revolutions of 411 and 404 . What Aristotle has to say about Athenian democracy is restricted to a fairly long account in Book 2 of the mixed Solonian democracy ${ }^{16}$ and some scattered references to ostracism, naturalization of foreigners by Kleisthenes, and a few other institutions. When democracy is discussed, the mention of Athens is outnumbered by references to Kyrene, Syrakusai, Rhodos, Kos, and other cities. Thus, Plato and Aristotle's critical account of democracy is, in my opinion, what it purports to be: an evaluation of democracy in general combining elements from many different poleis and disregarding many of the typical Athenian institutions. On the other hand, it is idiosyncratic in so far as it reflects Plato's and Aristotle's hostile view of popular rule. Democracy is invariably seen as the rule of the poor or the mob (demos in its social sense) and not as the rule of the whole of the people, which was 
the Athenian democrats' understanding of demos and demokratia. ${ }^{17}$ So much for Plato and Aristotle. Polybios took no interest in Athenian democracy and dismissed it in one sentence. ${ }^{18}$

But it is the Plato-Aristotle-Polybios view of democracy as one of the three basic types of constitution that is reflected in political philosophy and in political thought from the recovery of Aristotle's Politics about $1250^{19}$ to the rise of history in its modern sense in the beginning of the 19th century. During this period of more than 500 years the standard description of ancient Greek democracy includes the following seven elements:

1. Democracy is not described in its own right but only as one of the three basic forms of government: monarchy, oligarchy, and democracy.

2. The description is theoretical rather than historical. Democracy, that is government by the majority of the people, is mentioned in passing only as a possible form of government which nobody needs to take much notice of.

3. The view of democracy is mostly hostile, and when it is positive, democracy is nevertheless regarded as impracticable.

4. It is commonly held that the best form of government is some kind of mixed constitution, combining monarchic, aristocratic, and democratic elements.

5. In so far as democracy can be accepted, it is one of the elements in a mixed constitution not a pure constitution.

6. Occasional references to Athenian institutions are mostly to the famous legislator Solon, who was believed to be the father of a moderate mixed democracy.

7. The sources upon which this account of ancient democracy is based are Plato, Aristotle, and, sometimes, Polybios. In so far as the Athenian democracy is mentioned the main source is Plutarch's lives of Solon, Perikles, Demosthenes, and Phokion, as well as his other lives of Athenian statesmen.

Let me adduce an example to illustrate the seven points. In 1576, in the second of his six books on commonwealth, Louis Bodin wrote: ${ }^{20}$

There are only three types of state, or commonwealth, monarchy, aristocracy, and democracy. A state is called a monarchy when sovereignty is vested in one person, and the rest have only one to obey. Democracy, or the popular state, is one in which all the people, or a majority among them, exercise sovereign power collectively. A state is an aristocracy when a minority collectively enjoy sovereign power and impose law on the rest, generally and severally. All the ancients agree that there are at least three types of commonwealth. Some have added a fourth, composed of a mixture of the other three. Plato added a fourth type, or rule of the wise. But this, properly speaking, is only the purest form that aristocracy can 
take. He did not accept a mixed state as the fourth type. Aristotle accepted both Plato's fourth type and the mixed state, making five in all. Polybios distinguished seven, three good, three bad, and one composed of a mixture of the three good.

Then follow references to Dionysios of Halicarnassos and Cicero, and later, when democracy is briefly discussed, Solon is the only Greek statesman mentioned by Bodin.

Similar general descriptions of democracy as one of the three forms of government can be found in the works of Thomas Aquinas, ${ }^{21}$ Marsilius of Padua, ${ }^{22}$ Machiavelli, ${ }^{23}$ Thomas Hobbes, ${ }^{24}$ John Locke, ${ }^{25}$ Blackstone, ${ }^{26}$ James Mill, ${ }^{27}$ and many others. Thus, it would be misleading to say that the tradition of Athenian democracy was an important part of the 18thcentury revolutionaries' intellectual background.

The classical example that inspired the American and French revolutionaries as well as the English radicals was Rome rather than Greece. ${ }^{28}$ Thus, the Founding Fathers who met in Philadelphia in 1787 did not set up a Council of the Areopagus but a Senate that, eventually, met on the Capitol. And the French constitution of 1799, designed by Siéyès, had no board of strategoi but a triumvirate of consuls.

When tradition focused on Greece, the model was Sparta rather than Athens. ${ }^{29}$ Even as late as 1819 , when Benjamin Constant published his lucid pamphlet De la liberté des anciens comparée à celle des modernes he took the Spartan concept of political liberty to be typical of ancient Greece, ${ }^{30}$ whereas the Athenian concept of eleutheria (so strikingly similar to the modern concept of liberty) was brushed aside as an exception. ${ }^{31}$

When, occasionally, the model was ancient Athens, the praise goes, almost invariably, to the moderate, mixed Solonian democracy. John Adams, the second president of the United States, wrote as early as 1787 a long defence of the new constitutions of the liberated colonies and here he devoted some 20 pages to a description of Athenian democracy. ${ }^{32}$ It is an uncharacteristically long account of Athenian democracy; but it is, characteristically, about Solonian democracy and not, as a modern reader would expect, about the Athenian democracy from Kleisthenes to Demosthenes. Similarly, on the other side of the Atlantic, Montesquieu, in De l'esprit des lois ${ }^{33}$ followed by de Joucourt in Diderot's Encyclopedie ${ }^{34}$ admired Solon as the father of Athenian democracy, whereas Perikles is not mentioned, not even once. On the contrary, Athenian democracy in the age of Perikles - when discussed - was held up as a bugbear to warn modern champions of popular rule against the excesses of democracy. Thus, according to J.J. Rousseau, Periklean Athens was no longer a democracy, but a tyrannic 
aristocracy governed by 'savans et orateurs' ${ }^{35}$ But Solonian democracy is a historical myth known to the revolutionaries - directly or indirectly - from one page in the second Book of Aristotle's Politics ${ }^{36}$ and from Plutarch's Life of Solon. Aristotle's misleading and Plutarch's distorted picture of Athenian democracy obscured the Enlightenment's understanding of classical Athens.

There is one important exception to this general picture, namely Germany, where Greece was preferred to Rome and Athens attracted more interest than Sparta. Moreover, the ideal was not archaic but classical Athens with its liberty and democracy. This German tradition spans half a century from Johann Winckelmann in the mid-18th century to Wilhelm von Humboldt in the early 19 th century. According to Winckelmann, it was the Athenian liberal, democratic constitution that was responsible for the unmatched quality of Athenian art, ${ }^{37}$ and inspired by reading Demosthenes Humboldt planned, in 1807, to write the counterpart of Gibbon's Decline and Fall called: Geschichte des Verfalls und Unterganges der griechischen Freistaaten. As far as we can see from the preserved fragments, the Leitmotif was to be the individual freedom, cherished above all in classical Athens. ${ }^{38}$ But the German liberal humanism was quenched by the Prussian reactionaries in the 1820 s and, after a short revival in the wake of the 1848 revolutions, it was quenched once again by Bismarck and the conservatives. Contrary to the development in all other countries the later classical tradition in Germany turned from Athens to Sparta; and the praise of the Dorian race, exemplified by Spartan law and order, eclipsed the earlier admiration of Athenian liberty and equality. ${ }^{39}$

But in America, Britain, and France the focus of interest shifted in the course of the 19th century from Sparta to Athens and from Solon to Perikles and, finally, during World War One the British and the French expressed their admiration for the classical Athenian democracy, whereas the Germans with equal pride tended to identify themselves with the Spartan alliance of land powers that fought against the naval confederacy led by Periklean Athens or with Macedon under king Philip the Second who fought against the Athenian democracy, led by the lawyer Demosthenes.

Again a few examples will suffice: in 1915 all London buses had stuck up a bill with an English translation of Perikles' praise of liberty in the funeral oration. ${ }^{40}$ And in 1920 when Georges Clemenceau withdrew from politics he devoted his remaining years to literary work, including a biography of Demosthenes who defended Athenian liberty against the Macedonian imperialism. ${ }^{41}$ In Germany, on the other hand, Hermann Diels predicted, in 
1916, that once again Spartan nomos (Germany) would prevail against Athenian physis (Britain and France); and even after the defeat the German admiration for Sparta is reflected in the frequent quotation, in schoolbooks for example, of Simonides' famous epitaph on Leonidas and his men in Fr. Schiller's equally famous translation of it: Wanderer, kommst du nach Sparta ... ${ }^{42}$ As to the Macedonian example, I can refer to Engelbrecht Drerup who in 1916 saw Kaiser Wilhelm as a second Philip defeating the lawyer Demosthenes (Lloyd George). ${ }^{43}$

The re-appraisal of Athenian democracy during the 19th century is connected with the rise of history as a separate scholarly discipline with its own method. During the Enlightenment of the 18th century philosophy overshadowed history, but the roles were reversed when critical history emerged in the wake of the romantic movement of the early 19 th century. The change from the philosophical to the historical analysis of ancient democracy and from the critical view of the general type to the more positive account of the Athenian form took place gradually during the first half of the 19th century. The principal sources referred to were no longer Plato and Aristotle, but rather Herodotus, Thucydides, Demosthenes, and, after 1890, the Aristotelian Constitution of Athens. Solon was eclipsed by Perikles as the central figure and the negative view of Greek democracy was supplanted by a more favourable description of the classical Athenian democracy.

The new understanding of Athenian democracy can be traced back to three major historians one English, one French, and one German. The most important was George Grote who in the decade 1846-56 published his monumental History of Greece in 12 volumes. ${ }^{44}$ In 1851 appeared in France the Histoire de la Grèce ancienne by Victor Duruy, ${ }^{45}$ and in Germany Ernst Curtius wrote a Griechische Gechichte in 3 volumes, published in the decade $1857-67 . .^{46}$ It is worth noting that these three men were not just great scholars, they were also prominent persons. Grote was the leader of the radicals in the House of Commons, Duruy was minister of education under Napoleon III and Curtius was private tutor to the Prussian crown prince, Frederick Wilhelm I, who for a short period in 1888 was emperor of Germany. The three leading historians were all liberals, and they all took a favourable view of Athenian democracy, especially the democracy in the age of Perikles. George Grote was undoubtedly the most influential of the three, but as a historian he was inspired by the German critical school, especially by Böckh and Niebuhr, ${ }^{47}$ and the early German admiration for Periklean democracy and Athenian liberty, though on retreat in Germany itself after 1820, survived and was - via Grote transplanted to the Anglo-American sphere. 
Because of the historians' new approach the description of ancient democracy in political thought and philosophy has changed considerably during the last century and a half. It is no longer confined to a few theoretical remarks in connection with the enumeration of the three Aristotelian forms of government. Ancient democracy is now often described in more detail sometimes in a separate section that deals with the history of the concept of democracy. ${ }^{48}$ The reference is no longer to ancient democracy in general but rather to the Athenian democracy, especially the democracy in the age of Perikles.

I conclude that Athenian democracy may have inspired modern champions of democracy, but the tradition is later than usually believed. The focus of interest must be moved from the 18th century to the 19th and 20th centuries.

\section{Democracy as a Political System}

Democracy is both a set of political institutions and a set of political ideals. The two different aspects of democracy are - of course - closely connected (democrats believe that the democratic ideals are furthered by the democratic institutions more than by any other form of government). But, in an analysis of democracy, it is advisable to treat institutions and ideals separately. And this methodological principle applies not only to the study of contemporary democracy but also to the study of the history of democracy. Thus, - beginning with democracy as a political system - I will ask two questions: does any of the typical Athenian political institutions turn up later in world history and second - whenever a parallel is attested - did Athens serve as a model for those who introduced the institution in question? In this brief survey I will discuss two possible parallels. One concerns the people's assembly and the other voting procedure and sortition of magistrates.

In democratic Athens the most characteristic political institution was undoubtedly the $e k k l e s i a$, in which every adult male citizen had the right to speak and the right to vote. Several thousand citizens did in fact turn up regularly to debate political issues which were presented to the people after a prior consideration by the Council of Five Hundred. Then, after a debate in the ekklesia, the issue was decided by a majority vote taken by a show of hands. ${ }^{49}$

The most striking parallel to the Athenian ekklesia is the Swiss Landsgemeinde. It was introduced in the 13th century and still exists in one canton and four half-cantons. Several thousand citizens attend a major 
open-air political meeting. Every participant has the right to speak and the right to vote. All important matters must be laid before the people, but only after they have been considered by the Council, the Kantonsrat; then follows an open debate in the Landsgemeinde itself, whereafter the people decide the issue by a majority vote taken by a show of hands. ${ }^{50}$

The Athenian ekklesia and the Swiss Landsgemeinde are strikingly similar institutions ${ }^{51}$ but they cannot be connected. The freeholders of the small forest cantons, who created the medieval Swiss Landsgemeinde in opposition to the Habsburg princes, had no idea that their institution - in many respects - was an exact parallel to the Athenian ekklesia.

Another historical example of a popular political decision-making assembly is the Town Meeting in the New England states in North America. They go back to the early colonial period, and the first attested provision that regular town meetings be held was made in Cambridge, Mass. in December 1632. ${ }^{52}$ The Town Meeting, however, sprang from the puritan congregation, ${ }^{53}$ the ekklesia in the Christian meaning of the term, and there is no indication that the New England colonists had the Athenian ekklesia in mind when they created their town meetings.

My second example concerns election and sortition of officials. The elaborate Athenian procedures ${ }^{54}$ are matched by the sometimes even more complicated procedures for election and selection by lot of magistrates practiced in most Italian city states in the Middle Ages. The election in Venice of the Doge ${ }^{55}$ and in Florence of the priors and the Gonfaloniere ${ }^{56}$ are the two best known examples but there are scores of others in other cities. The way the ballot and sortition were practised in the Italian cities is often strikingly similar to the Athenian way of voting by ballot and selecting by lot. ${ }^{57}$ But, once again, the parallel is not due to any tradition; there is no unbroken line from the Greek city states to the medieval Italian cities. If there is a tradition, it is Roman and not Greek, but the Roman way of voting was very different from the Athenian, ${ }^{58}$ and the lot was used mainly for establishing a sequence or for the distribution of tasks among, e.g., the praetores. ${ }^{59}$ The Romans did not approve of, and never adopted, the Greek democratic method of selecting magistrates by lot. Furthermore, the complicated voting procedure and sortition of magistrates were developed in the Italian cities in the 13th century, long before the rediscovery of Greek literature. Thus, for chronological reasons alone, we can reject all attempts to connect the Italian use of the lot and the ballot with the Renaissance and the revived knowledge of ancient Athenian political institutions.

To sum up, the two examples I have discussed show that strikingly similar institutions have existed without any sign of tradition to explain the 
similarity. Not a single Athenian institution seems to have left its mark on posterity and all the similarities between Athenian and later political institutions are fortuitous or rather they are not due to any tradition.

In a much broader and vaguer sense, however, it is possible to establish a connection between Athenian democracy as a political system and modern democracies. Until about 1790 democracy was invariably taken to mean government by the people, over the people, through a popular assembly. The concept of representative democracy made its first appearance in a letter from Alexander Hamilton ${ }^{60}$ written in 1777. But apart from a short bloom in the 1790 s the concept developed only slowly, ${ }^{61}$ and it took several decades for the concept of representation to be ingrafted upon the concept of democracy (to use a metaphor coined by Thomas Paine in Rights of Man) ${ }^{62}$ The first really important political movement launched under the banner of democracy - that is representative democracy - was Andrew Jackson's democratic party set up in 1828 and centred in the south and west of the United States. ${ }^{63}$ And on the other side of the Atlantic, it was Alexis de Tocqueville's De la démocratie en Amérique more than any other work that led to a general acceptance of the idea of representative democracy. But as late as 1848 the new Swiss federal constitution treated democracy and representation as direct opposites. ${ }^{64}$

From the middle of the 19th century the concept of representative democracy prevailed. Pure democracy was now called direct democracy, and the simple term democracy was taken to denote the indirect or representative form of popular government. ${ }^{65}$ From now on an account of democracy was regularly opened by explaining the opposition between indirect and direct democracy, which was now a purely historical concept; and in this context it became common both to refer to the ancient Greek demokratia in general and, specifically, to adduce classical Athens as the obvious historical example. ${ }^{66}$

But in addition to this parely historical perspective Athenian democracy, or perhaps the modern myth about Athenian democracy, has appeared in contemporary discussions about what democracy ought to be. Until about 1850 democracy was viewed very critically and mostly rejected ${ }^{67} \mathrm{It}$ fostered demogogues and led to factions and, in its pure form, it was impractical in modern nations.

During the period from the mid-19th century to World War One the concept of representative democracy became increasingly palatable and even popular. And from c. 1915 democracy had become universally accepted; we may remember President Wilson's slogan: 'to make the World safe for democracy.' Democracy is invariably a positive term, sometimes 
even a mere 'hurrah-word', ${ }^{68}$ and it goes without saying that the most democratic form of government is the best form of government.

There can be no denying, however, that direct democracy is more democratic than representative democracy, and for many contemporary champions of democracy it is a little disquieting that the prevailing form of representative democracy is not as democratic as direct government by the whole of the people. Representative democracy presents a major problem: the problem of participation. It was not felt in the 19th century when democrats everywhere fought for universal suffrage, but after 1918 when universal suffrage became universally accepted the democrats had to face the problem that the people did not use the democracy they had got. Especially since the 1950 s a growing ignorance and apathy among the voters are felt to be a major threat to democracy in the real sense of the word. ${ }^{69}$ In this context it has become common to look back to ancient Athens and to envy the Athenians their degree of political participation. ${ }^{70}$

The most amazing aspect of Athenian democracy is indeed the degree of participation by the 30,000 adult male citizens. Every year the Athenians convened 40 ekklesiai which were regularly attended by no less than 6,000 citizens. On about 200 court days thousands of jurors were appointed by lot from a panel of 6,000 citizens aged 30 or more. Most Athenians served at least one year in the Council of 500. And every year at least 700 other magistrates were elected or selected by lot. ${ }^{71}$ This massive participation is unparalleled in world history. It has elicited admiration in some, ${ }^{72}$ but aversion in others who prefer to point out, correctly, that political participation was restricted to adult male citizens who constituted only a minority of the population of Attica ${ }^{73}$ and, furthermore, that even in democratic Athens power was in the hands of a small elite of politically active citizens who dominated the democratic institutions. On the other hand Athens is held up as a model by those who advocate more participation as an essential element in democracy. What could be achieved in ancient Greece must be achieved again, either by reforming the representative democracy or by reintroducing some kind of direct democracy. The latest development is the new television democracy - teledemocracy as it is called - by which technology will permit all citizens to become directly involved in public policy making. ${ }^{74}$ When electronic voting via cable TV and similar futurist devices are discussed the two models most often referred to are the New England town meeting ${ }^{75}$ and the Athenian ekklesia. ${ }^{76}$

In conclusion, the tradition of Athenian democracy as a political system has become prominent only during the last century and mostly in connection with the general discussion of political participation. It was not the 
philosophers of the Enlightenment but the historians in the wake of Romanticism who were responsible for the reconstruction and reassessment of the Athenian classical political institutions; and, apart from Tom Paine, ${ }^{77}$ Camille Desmoulins, ${ }^{78}$ and a few others, the Athenian example was of little importance to the revolutionaries on both sides of the Atlantic.

\section{Democracy as an Ideology}

I will now turn from democracy as a political system to democracy as an ideology and discuss the relation between democracy, liberty, and equality. Let me illustrate the contemporary connection between the three concepts by quoting a recent account of liberal democracy:

Democracy, equality and liberty form, as it were, the three points or angles of a triangle so that lines of relationship go not only from equality and liberty to connect with each other at the third point, democracy, but one also forms the final side of the triangle connecting equality directly with liberty. ${ }^{79}$

Similarly, in classical Greece the concepts of demokratia, eleutheria, and iso(nomia) were closely connected. ${ }^{80}$ The three concepts were interpreted approvingly by Perikles in his funeral oration which I quoted before but disapprovingly by, for example, Isokrates whom I will quote here: the ancestors did not introduce a constitution 'which trained the citizens in such a fashion that they looked upon insolence as democracy, lawlessness as liberty, impudence of speech as equality, and licence to do what they pleased as happiness'. ${ }^{81}$

Who in Europe since the Enlightenment combined democracy with liberty and equality so that the three concepts formed a unified political ideology, and when the triangle was formed, was classical Athens conceived as the model of modern democratic ideology?

The appraisal of liberty and equality as the two basic political values has sprung from three different sources: the American revolution, the French revolution, and the English utilitarians. But only the British radicals and utilitarians were prone to connect liberty and equality with democracy. The three leading figures were Jeremy Bentham, Tom Paine, and James Mill. Tom Paine does praise classical Athens, ${ }^{82}$ and his work testifies to a classical tradition of some importance. In James Mill's essay on government, however, the only reference to classical democracy is rather critical. ${ }^{83}$ And if Bentham was inspired by ancient Greek democracy he concealed it remarkably well. ${ }^{84}$ Furthermore, the early utilitarians were 
isolated in their praise of democracy, as Bentham admits. ${ }^{85}$ Apart from a few years just before 1800 the negative evaluation of democracy prevailed in the United States until the new Jacksonian democracy in the $1820 \mathrm{~s}^{86}$ and in Europe until the revolutions of 1848, and on both sides of the Atlantic it is hard to connect the reappraisal of democracy with the Athenian example. The leading Jacksonian democrats were middle-class business men with little education in general and none in classics, whereas the strong classical tradition lived on among the planters of the southern Atlantic States, and they preferred an Aristotelian type of state with 'natural slaves' as a prominent feature and were less concerned with the Athenian example. ${ }^{87}$

In Europe, the first important attestation of the triangle democracyliberty-equality is in de Tocqueville's De la démocratie en Amérique ${ }^{88}$ but de Tocqueville had hardly anything to say about the classical tradition. One short chapter on the educational effect of reading classical literature, that is all ${ }^{89}$ Furthermore, de Tocqueville had mixed feelings about democracy and tended to believe that democracy might be conducive to equality but could easily become a threat to liberty. ${ }^{90}$ The picture changed only slowly. In the course of the 19th century democracy became gradually a positive concept compatible with both liberty and equality. An early unquestionable attestation in French political thought of a positive view of the triangle democracy-liberty-equality can be found in E. Vacherot's book Le démocratie from 1860 in which he writes: 'Démocratie, en bon langage, a toujours signifié le peuple se gouvernant lui-même; c'est l'égalité dans la liberte. ${ }^{91}$ The book was published under Napoleon III and cost its author a short term of imprisonment.

In Germany the revolutions of 1848 brought back in a glimpse of the political ideals from the turn of the century Demokratie-GleichheitFreiheit. But reaction came soon ${ }^{92}$ and in so far as the democrats looked back for a model, they praised democratic aspects of the Reformation in Germany, ${ }^{93}$ or even 'Die germanische Urdemokratie', briefly described by Tacitus $^{94}$ and again by Montesquieu, ${ }^{95}$ whereas the classical Athenian democracy was less important.

In Britain the concepts of democracy-liberty-equality were juxtaposed first by George Grote in his History of Greece ${ }^{96}$ and then by John Stuart Mill in his essays on liberty and on representative government; but, deeply influenced by Plato, Mill believed, like most of his contemporaries, that ancient political liberty was fundamentally different from modern individual liberty. ${ }^{97}$ Thus, George Grote's appraisal of individual liberty as a principal feature of Periklean democracy was far from generally accepted even in his own circles, and his work was soon eclipsed by Fustel de 
Coulanges' who, in La cité antique, successfully advocated the erroneous view that individual liberty was unknown in the ancient world. ${ }^{98}$

\section{Conclusion}

In the 18th century, when the classical tradition was a strong element in the creation of public opinion, the tradition of Athenian democracy did not count for much. The ancient democracy referred to was the general type critically described by Plato and Aristotle. If the Athenian example was referred to specifically, it was the ancestral Solonian mixed democracy, a historical phantasy known from Aristotle and from Plutarch's life of Solon. In the nineteenth century, when the critical account of Greek democracy was replaced by a more favourable view of Athenian democracy in the age of Perikles, the classical tradition did not matter as much as it did in the age of the revolutions. No direct tradition connects the Athenian triad democratia-eleutheria-isonimia with its modern counterpart: democracyliberty-equality. And I will end with a warning. Tradition must not be overrated, and, conversely, we must not underrate man's capacity in similar circumstances to develop strikingly similar - but basically unrelated - institutions and ideals. A study of the institutions of direct democracy, principally the people's assembly convoked by a probouleutic council reveals a striking similarity between the ancient Athenian ekklesia and the medieval Swiss Landsgemeinde; but there is no trace of any Greek impact on the medieval institution. Again, a study of the democratic political ideals shows a striking similarity between Athenian democratic values and the liberal democratic values of the 19th and 20th centuries. Here there was a classical tradition of some importance but I think it came later than often believed and that the direct Athenian impact on modern political ideology was negligible compared with other forces.

\section{NOTES}

1. A. Andrewes, 'Kleisthenes' Reform Bill', CQ 27 (1977), 246-7; M. Ostwald, 'The Reform of the Athenian State by Kleisthenes', CAH IV (1988), pp. 306-7.

2. Thuc. 2.41.1.

3. Encyclopadia Britannica 15th edn. (1955), vol. 7 p. 182.

4. Thuc. 2.37.1-3.

5. Cf. Thuc. 5.81.2, 8.38.3, 8.53.3, 8.89.2.

6. Cf. A. W. Gomme, A Historical Commentary on Thycydides II (Oxford, 1956), p. 108.

7. M. H. Hansen, Was Athens a Democracy? Popular Rule, Liberty and Equality in Ancient and 
Modern Political Thought, Det Kongelige Danske Videnskabernes Selskab. Historisk-Filosofiske Meddelelser 59 (1989).

8. Cf., e.g., J. Rufus Fears in his 'Preface' to W. R. Connor, M. H. Hansen, K. A. Raaflaub, and B. S. Strauss, Aspects of Athenian Democracy (Copenhagen, 1990), pp. 4-5.

9. On Revolution (1963, Pelican edn 1973), p. 196.

10. Thuc. 2.37.1, 3.82.1; Arist. Pol. 1307b23-24; Meiggs and Lewis, 40.

11. H.-J. Gehrke, Jenseits von Athen und Sparta (Munich, 1986).

12. Arist. Pol. $1286 \mathrm{~b} 20-22,1291 \mathrm{~b} 7-13,1296 \mathrm{a} 22-23,1301 \mathrm{~b} 39-40$.

13. Grg. 515C-519A.

14. A. H. Chase, 'The Influence of Athenian Institutions upon the Laws of Plato', HSCP 44 (1933), 131-92.

15. Pol. 299B-C.

16. Pol. $1273 \mathrm{~b} 35-74 \mathrm{a} 21$.

17. Hansen, The Athenian Democracy in the Age of Demosthenes (Oxford, 1991), pp. 69, 125, 301.

18. Polyb. 6.43.

19. On the revival of Arist. Pol. with Wilhelm of Moerbeke's Latin version c. 1250, cf. J. Aubonnet in the Budé edn. Vol. I (1968), pp. cxlviiff.

20. Les six livres de la république (1576), 2.1, 7 here quoted from Tooley's translation (Oxford, 1951), pp. 51-52.

21. De Regimine Principum 16.

22. Defensor Pacis $1.8 .2-3$.

23. Discorsi $1.2 .3-4,11-12$.

24. De Cive 7.1, 5-7.

25. The Second Treatise of Government 132.

26. Commentaries 1.2.7.

27. 'Government' in Encyclopedia Britannica (1820), pp. 3-5.

28. M. Reinhold, 'Eighteenth-Century American Political Thought', in Classical Influences on Westem Thought A.D. 1650-1870, ed. R. R. Bolgar (Cambridge, 1979), pp. 225, 233, and passim.

29. E. Rawson, The Spartan Tradition in European Thought (Oxford, 1969), pp. 268-300; Reinhold (n. 28), pp. 228 et alibi.

30. Reprinted in M. Gauchet, De la liberté chez les modernes:écrits politiques (Paris, 1980), pp. 494-5, 500,509 .

31. Ibid. pp. 496, 500 with note 14. Cf. also his De l'esprit de conquête et de l'usurpation (1814), II.6 and 7.

32. Defence of the Constitutions of Government of the United States of America (1787-8) in Works (Boston, 1851), IV.472-92.

33. De l'esprit des lois (edn. Garnier Paris, 1967), I.12-15, 25, 48-49, 52, 54, 122; II.107, 282.

34. 'Démocratie', Encyclopedie IV (1754), 816-18.

35. Discours sur les sciences et les arts in Oeuvres III (Pléiade edn. Paris, 1967), 10, 12, 56, (lettres) 68, 81; Sur l'économie politique (ibid.), 246.

36. Pol. $1273 \mathrm{~b} 35-74 \mathrm{a} 21$.

37. Geschichte der Kunst des Altertums 1.4 (130-3).

38. Fragments in Werke in fünf Bänden (1981), II.74, 77, 84.

39. Carl Otfried Müller, Die Dorier (1824).

40. Cf. F. M. Turner, The Greek Herilage in Victorian Britain (London, 1981), p. 187.

41. Démosthène (Paris, 1924).

42. 'Ein antikes System des Naturrechts', Internationale Monatsschrift für Wissenschaft Kunst und Technik 11 (1916-17), 82-102; E. Neustadt and G. Röhm, Geschichte des Altertums (1924); W. Hack, Geschichte der Griechen und Römer (1930). Cf. the famous short story by Heinrich Böll, 'Wanderer, kommst du nach Spa...'(1950).

43. Aus einer alten Advokatenrepublik (Paderborn, 1916), pp. 1-4: 'Advokaten gegen Könige.'

44. On Periklean Athens see Vol. 6 (1848), Part 2, Chapters 46-48, especially pp. 176-84 with a long quotation from Perikles' funeral oration and Grote's praise of Athenian democracy.

45. On Periklean Athens see Vol. 2 Chapter 19. 1 (Périclès) and 3 (La Constitution athénienne), pp. $145-54$ and $196-214$ in the 1888 edition.

46. On Periklean Athens, see Vol. 2, Book 3, Chapter 3 (pp. 157-280): 'Die Friedensjahre'.

47. History of Greece I. preface xvi; J. S. Mill, review of Grote, History of Greece VIII, Edinburgh 
Review Oct. 1853, in Collected Works of Fohn Stuart Mill 9 (Toronto, 1978), pp. 323, 328.

48. Cf., e.g., G. Sartori, Democratic Theory (Westport, 1962), pp. 250-77; D. Held, Models of Democracy (Cambridge, 1987), pp. 13-35.

49. Arist. Ath. Pol. 43-44.

50. M. Kellenberger, Die Landsgemeinden der Schweizerischen Kantone (Winterthur, 1965).

51. Hansen, 'The Athenian Ecclesia and the Swiss Landsgemeinde', The Athenian Ecclesia: a Collection of Articles 1976-83 (Copenhagen, 1983), pp. 207-26.

52. J. F. Sly, Town Government in Massachusetts 1620-1930 (Cambridge, Mass., 1930).

53. S. H. Stout, The New England Soul (Oxford, 1986), p. 22.

54. Hansen (n. 17), pp. 197-9, 230-5.

55. R. Finlay, Politics in Renaissance Venice (London, 1980), pp. 141-2.

56. J. M. Najemy, Corporatism and Consensus in Florentine Electoral Politics 1280-1400 (Chapel Hill, 1982).

57. Compare, for example, the voting procedure in the Athenian 5th-century courts, described by A. Boegehold in Hesperia 32 (1963), 367-8, with the procedure described in D. Waley, The Italian CityRepublics (London, 1969), pp. 30-31.

58. L. Ross Taylor, Roman Voting Assemblies (Ann Arbor, 1966), pp. 34-58.

59. V. Ehrenberg, 'Losung', $R E$ XIII.2 (1927), 1493-1504.

60. Letter from Alexander Hamilton to Gouverneur Morris of May 19th, 1777.

61. R. R. Palmer, 'Notes on the Use of the Word "Democracy" 1789-99', Political Science Quarterly 68 (1953), 203-26.

62. Rights of Man, ed. B. Kuklick (Cambridge, 1989), p. 170.

63. J. Roper, Democracy and its Critics: Anglo-American Democratic Thought in the Nineteenth Century (London, 1989).

64. Constitution de la Conféderation Suisse du 12 Septembre 1848.

65. Cf. de Tocqueville's report of 15th Jan. 1848 on the subject of $M$. Cherbuliez' book entitled On Democracy in Switzerland, printed as Appendix II in J. P. Mayer's edition of De la démocratie en Amérique (New York, 1966), p. 740.

66. Cf., e.g., the entry 'Democracy' in the 11th edn. of Encyclopcedia Britannica VIII (1910), pp. 1-2 and in International Encyclopaedia of the Social Sciences (1968), pp. 112-21.

67. Even as late as 1847 George Grote could still write in his History of Greece IV.346: 'Democracy happens to be unpalatable to most modern readers.'

68. B. Holden, The Nature of Democracy (London, 1974), p. 2.

69. Holden (n. 68), pp. 140-6.

70. B. Campbell, 'Paradigms lost: Classical Athenian Politics in Modern Myth', History of Political Thought 10 (1989), 189-213; M. I. Finley, Democracy Ancient and Modern (New Brunswick, N.J., 2nd ed. 1985), pp. 33-37.

71. Hansen (n. 17), p. 313.

72. J. S. Mill, Considerations on Representative Govermment (1861), p. 197.

73. J. Bentham, A Fragment on Govermment (1776), 2.34 with note 2.

74. F. Chr. Arterton, Teledemocracy: Can Technology protect Democracy? (Washington, 1987).

75. B. J. Barber, Strong Democracy: Participatory Democracy for a New Age (Berkeley, 1984), pp. $239-40,268,272,273-8$.

76. I. McLean, Democracy and New Technology (Cambridge, 1989), pp. 157-61.

77. Rights of Man (n. 62), p. 170.

78. H. T. Parker, The Cult of Antiquity and the French Revolutionaries (Chicago, 1937), p. 76 with n. 7 et alibi.

79. B. Holden, Understanding Liberal Democracy (Oxford, 1988), p. 28.

80. Arist. Pol. 1310a28-33. Hansen (n. 7), pp. 3, 25-28.

81. Isok. 7.20 .

82. Above n. 77.

83. An Essay on Govermment (1820), ed. C. V. Shields (New York, 1955), p. 55.

84. H. O. Pappé, 'The English Utilitarians and Athenian Democracy', in Bolgar (n. 28), p. 296.

85. Plan of Parliamentary Reform (1817) in The Works of Bentham 10 (London, 1839), p. 438: 'This bugbear word democracy.'

86. R. L. Hanson, 'Democracy', in Political Innovation and Conceptual Change, ed. T. Ball, J. Farr, and R. L. Hanson (Cambridge, 1989), pp. 78-9. 
87. E.g., John C. Calhoun and George Fitzhugh. The only intellectual who focused on Athens was, apparently, Hugh Swinton Legare: cf. W. W. Briggs, Jr., 'Classical Influence in the Southern Response to the Constitution', unpublished paper read in Boston in Sept. 1989.

88. De la démocratie en Amérique Vol. 2, Part 2, Chapter 1.

89. Ibid. Vol. 2, Part 1, Chapter 15: 'Pourquoi l'étude de la littérature grecque et latine est particulièrement utile dans les sociétés démocratiques.'

90. The title of Vol. 2, Part 1, Chapter 2 is: 'Pourquoi les peuples démocratiques montrent un amour plus ardent et plus durable pour l'égalité que pour la liberté.'

91. La démocratie (Paris, 1860), p. 7 [= de Tocqueville, 2.2.1, but without the modifications].

92. W. Conze, 'Demokratie', Geschichtliche Grundbegriffe I (Stuttgart, 1972), pp. 885-6.

93. Georg Gottfried Gervinus, Einleitung in die Geschichte des neunzehnten Fahrhunderts (Leipzig, 1853).

94. Germania 11.

95. Montesquieu (n. 33), 1.170.

96. History of Greece IV.345; VI.180.

97. On Liberty (1859), Chapter 1 (pp. 19-20 in the Prometheus Books edn.).

98. La cité antique (Paris, 1864), 3.7.

NOTES ON CONTRIBUTORS

JACQUELINE DE ROMILLY: Member of the Académie française. MOGENS HERMAN HANSEN: Reader in Classical Philology, University of Copenhagen.

H. S. VERSNEL: Professor of Ancient History, University of Leiden. ERIKA SIMON: Professor of Classical Archaeology, University of Würzburg.

MOLLIE DIXON: now retired, has taught in Direct Grant, Grammar, and Comprehensive Schools.

JOHN DIXON: now retired, was Principal Lecturer, Bretton Hall College H.E. 